\title{
Bør vi dra på vitenskapelige reiser?
}

\author{
Det er viktig å reise ut og få nye impulser, men det er også viktig å ivareta jobbforpliktelsene \\ hjemme. Dessuten er det vesentlig å veie utgifter opp mot utbytte. Ikke-målbare effekter må \\ tas med i regnskapet.
}

Reiser våre medisinske forskere for mye eller for lite? For en travel kliniker er trolig begge deler like sant. Uansett tyder mye på at kongressreiser kan ha utilsiktede positive bivirkninger. Johannes Bøe (1909-95) var professor $\mathrm{i}$ indremedisin på Medisinsk avdeling B ved Haukeland universitetssykehus. Han var en sterk og fast leder, som regel meget forekommende, men kunne av og til si kraftig ifra. Av flere grunner ble avdelingen til daglig kalt Med. avdeling $B \emptyset$ ! Som ekspert på infeksjonssykdommer og tropemedisin hadde han reist mer enn de fleste. På avdelingen bygde han opp et internasjonalt forskningsmiljø på infeksjonssykdommer sammen med sin etterfølger Claus Ola Solberg.

I et innlegg i Nordisk Medicin i 1972 skrev han med bekymring om den økende reisevirksomheten som skjedde i medisinen på de tider. Bekymringen gjaldt ikke alt han visste om sykdommer man kunne pådra seg under kongresser i eksotiske land: Man risikerte å bli sengeliggende i bushen eller det kunne oppstå akutt oppkast og diaré på nattfly. Enda verre var det når parasitter kom krypende ut av kroppsåpninger midt under møtet. Nei, det han skrev om var at vi ikke skulle forsømme arbeidet hjemme ved å dra på kongresser i tide og utide.

I dag, fire tiår senere kan man spørre: Reiser vi for mye eller for lite på kongresser? Og som Bøe foreslår: Finnes det alternative former for faglig kontakt og informasjonsutveksling? Nå finnes det mange former for elektronisk kommunikasjon, og det er lett å gjennomføre møter ved bildeoverføring.. Det kan selvsagt være i arbeidsgiverens interesse at vi ikke reker omkring, men i stedet holder oss til avdelingen og heller bruker lunsj og nødvendige småpauser på naturens vegne til internasjonal kommunikasjon. I en travel klinisk hverdag med presset arbeidssituasjon teller både timer og minutter, og da må mange som forsker i kliniske stillinger, både overordnede og de i utdanningsstillinger gi avkall på kongressreiser. Selv om han for så vidt hadde rett om samtiden, spørs det om ikke Johs. Bøe tok grundig feil om fremtiden. På grunn av tidspresset i rutinearbeidet reiser medisinske forskere heller for lite enn for mye.

For hardt pressede underordnede leger som skal forske på si', kan det faktisk øke produktiviteten om vedkommende foretar en og annen kongressreise til et behagelig og eksotisk land, særlig hvis sesjonene er korte og foredragene få. Da kommer de uthvilte og oppfrisket tilbake med god ballast av kunnskap, klare til å kaste seg inn i den travle kliniske hverdagen igjen. Kanskje har de til og med fått tid til å skrive mer på et viktig manuskript mens de var underveis. Dette skulle vi ha diskutert med Johs. Bøe dersom han ennå hadde vært blant oss. Jeg er sikker på at han hadde hatt full forståelse. Og til den utslitte, forskende klinikeren på store avdelinger er det bare å si: Ha en god tur med god samvittighet.

\section{Ole Didrik Lærum}

ole.laerum@gades.uib.no

Ole Didrik Lærum (f.1940) er professor (adj.) på Københavns Universitet og professor emeritus på Universitetet i Bergen.

\section{Kongresser og kongressreiser}

\author{
Tidsskrift for Den norske laegeforening 1972; 92, 520
}

Enten er han borte, nettopp reist til en eller annen kongress, eller man finner den opptatte mann ved skrivebordet bak en pyramide av post - nettopp kommet hjem fra en kongress, konferanse, et symposium, kurs eller seminar. Store kongresser, små kongresser, åpne kongresser eller lukkede kongresser, spesialiserte kongresser, interdisiplinære kongresser: det er alltid noe for enhver smak, for enhver årstid, for ethvert klima og for ethvert påskudd.
Påskudd ja, er det ikke påskudd godt nok at man vil følge med $i$ alt det nye som strømmer på? Er det ikke prisverdig at man vil holde seg på toppen? Er det ikke nødvendig å stifte nye bekjentskaper og gjenoppfriske gamle? Har man ikke plikt til å vise et ansikt utad, vise at man arbeider med noe?

Jo, det er så innlysende riktig og nødvendig alt sammen. Når dertil kommer at våren er fin og kommer tidlig i Italia og at Firenze er en deilig by, så kan noen hver en mørk novemberdag ha lyst til å melde seg på en kongress der. Utgiftene behøver heller ikke bli altfor tyngende: det er som regel noen fonds å søke, forskjellige myndigheter kan komme inn i bildet («it doesn't matter what racket it is as long as you get the trip»). Kemneren pleier også gjerne å se i nåde til den som reiser til beste for institusjonen eller bedriften. 
Ikke så rart da at mange kongresser blir rene gigantarrangementer: 10 seksjoner, simultanoversettelse, internt TV, et mylder av teknisk fullkommenhet. Finner man en bortgjemt benk og har tid til å reflektere litt over det som foregår, dukker kanskje følgende formastelige tanke (1) frem: er ikke her forholdet mellom masse og hjernevirksomhet omtrent som hos de forhistoriske kjempeøglene?

Nå er ikke «kongresseriet» noe eget for medisinernes verden. Det er sannsynligvis verre i offentlige etater, og det er i sine forskjellige former sannsynligvis betydelig verre i forretningslivet (2): «kongresseriet er nemlig ikke et meningsfylt svar på behovet for viten og faglig innsikt, men en temmelig grumset blanding av form og innhold, et produkt av ringe verd, men med uomtvistelig salgsappell». Kongresseriet har «ytterst betenkelige følger: Et slags vellevnet som seiler under falsk flagg». Det er harde ord, satt på spissen, men egnet til ettertanke.

Kongressmanien som er kosmopolitisk utbredt er meget smittsom, meget mer smittsom enn kolera. I motsetning til kolera hvor prevalensen er størst hos dem som står lengst nede på stigen («if you wear a collar and tie you are unlikely to get cholera») så angriper kongressykdommen fortrinnsvis den som står høyere i hierakiet.

Og her er et av kjernepunktene: Hvis det gjelder å få nye impulser, hvis det gjelder å snappe opp nye vitenskapelige resultater (sjelden på kongresser), hvis det gjelder å bedre samarbeidet institusjonene og landene imellom, da er det de unge man må satse på. De unge er i mindretall på de større kongressene nå.

Bevilgninger til kongressreiser tar en ikke liten del av enkelte bevilgninger til vitenskapelig formål. En del av pengene kunne sannsynligvis brukes bedre ved å sende unge lovende leger ut for å arbeide ute en tid. De ville da knytte bånd som var sterkere og nyttigere enn dem som blir til under en kongress eller på en kongressmottagelse.

Selvsagt vil man fortsatt ha «kongresser» $i$ en eller annen form, men man må være oppmerksom på utvekstene.

En moderne og sannsynligvis mer givende form for internasjonal møtevirksomhet er små symposier med begrenset og utvalgt deltagelse og med helt spesifikt emnevalg. Dem kommer det noe ut av, men de har en svakhet som all (nødvendig) spesialisering: det blir stadig vanskeligere å bygge bro over til andre spesialiteter.

Kongressreisene kunne innskrenkes en del uten at noe vesentlig gikk tapt hvis medisinens menn mer tok moderne telekommunikasjon i bruk enn de gjør nå. De er ofte gammeldagse slik. Skal man snakke med en mann i Neapel og en i San Francisco, så er det urasjonelt å reise til en kongress i Atlantic City for å treffe dem der. Shippingfolk har funnet ut at det er andre, mer rasjonelle og billigere - måter å kommunisere på.

Og kongressens resultater: Ja dem har man gjerne med seg i kofferten eller de ligger på ens skrivebord når man kommer hjem.

I en verden som blir mindre for hver dag er arbeid over landegrensene stadig mer nødvendig, men ikke alle kongresser og kongressreiser er like nødvendige.

Johs. Bøе

Brit. Med. J. 1967 (I), 520

2. Bedriftsøkonomen 1971, 8, 430-431 